\title{
The Triangle of Knowledge Sharing, e-Marketing Capability, Marketing Performance
}

\author{
Lia Nirawati *) \\ Rangga Restu Prayogo **)
}

\begin{abstract}
Today's marketing activities have employed information technology to overcome the challenges of marketing sustainability in getting more resources and meeting greater expectations for building lasting relationships with customers. The ability in e-marketing represents business organizations competence in the use of the internet and other information technology to be able to facilitate effective and efficient interactions with customers. One of the marketing developments is e-Marketing capability. Information technology helps business organizations to be able to carry out online marketing capabilities. Various organizational capabilities in managing electronic-based marketing are based on knowledge sharing by business organizations to improve marketing performance. The purpose of this research is to see the extent of knowledge sharing and eMarketing capability effect on marketing performance. This research used explanatory with a quantitative approach. The respondents are the students who have products that are marketed in business incubators. The questionnaire was given to 101 respondents with a sampling technique of purposive sampling. The results of the study show that knowledge sharing cannot influence eMarketing capability, knowledge sharing can influence marketing performance, and e-Marketing capability cannot influence marketing performance.
\end{abstract}

Keywords: Knowledge Sharing; e-Marketing Capability; Marketing Performance; Business Incubation

\section{INTRODUCTION}

\subsection{Research Background}

Several studies describe that business organizations can increase sales and activities to customers through information technology into marketing practices by business organizations to encourage effective interaction with customers (Prayogo \& Kusumawardhani, 2016; Salo, 2017). Assimilation of information technology in marketing activities is referred to as e-marketing. Emarketing activities include a series of technological activities that allow interactions that are often used in the business-to-business (B2B) industry including customer management relationships that use software, sales force automation, e-commerce websites, and extranets (personal websites provided for customers) (Trainor, Rapp, Beitelspacher, \& Schillewaert, 2011). The ability in emarketing represents business organizations competence in the use of the internet and other information technology to be able to facilitate effective and efficient interactions with customers. This interaction provides customers with simultaneous access to business organization resources and information (Chuang, 2016).

The result of the studies (Yu, Ramanathan, \& Nath, 2017) explains that e-marketing technology goes beyond internet-based advertising and communication that include technology to support several functions of marketing including customer relationship management, sales activities, customer support, marketing research, and marketing planning. e-Marketing has the potential to create value in various ways. First, by providing connections that are close to business organization processes, e-Marketing provides customers with direct access to business organization 
resources. For example, the customers can easily conduct business interaction with the business organization because the company provides customized support extranets for their customers. Typically, this extranet enables customers to access relevant support, product documentation, and electronic communication (Monim \& West, 2010). In this case, the customer becomes very integrated with the product development of business organizations with a much larger cycle in the customer-company information section. This extranet technology not only provides customers with direct information to business organization resources, but it also provides vast information about customers based on product demand and use for product management purpose. This form of information sharing plays an important role in developing and maintaining customer relations or often referred to as e-Marketing capability (Najafi-Tavani, Sharifi, \& Najafi-Tavani, 2016). EMarketing capability is the integration process of a business organization in collecting and using the knowledge and skills to manage internal resources and directly adapt to the external environment through information technology (Tang, Fu, \& Xie, 2015). Some research results explain that eMarketing capability can be influenced by knowledge sharing in business organizations. Another result of the study (Tang, Fu, \& Xie, 2015) explains that knowledge is a source of organizations that create value and innovation. Every business organization needs knowledge as a source that must be learned and shared for all existing business organizations (Ahmed, Kristal, \& Pagell, 2014). Knowledge sharing is related to learning organization so that every organization that implements eMarketing capability must know to run extranet as a communication tool for customers in creating innovative products. The results of the study (Chari, Balabanis, Robson, \& Slater, 2017) also explain that knowledge sharing has a positive and significant effect on e-Marketing capability in companies in the UK. The results of the study (Ritala, Olander, Michailova, \& Husted, 2015) explain that knowledge sharing can also have a positive influence on marketing performance in creating innovative products that improve marketing performance. E-Marketing capability as an electronic-based marketing capability has a positive impact on marketing performance run by business organizations, e-Marketing capability based on information technology can help marketing performance in effective and efficient marketing and sales activities. The results of the study indicate that e-Marketing capability has a positive and significant impact on the sustainability of marketing performance results (Efrat, Gilboa, \& Yonatany, 2017). Thus, dynamic marketing can be overcome by knowledge sharing and e-marketing capabilities (Cacciolatti \& Lee, 2016).

\subsection{Research Problem}

a) Does a knowledge sharing that includes tacit and explicit knowledge have a significant effect on e-Marketing Capability and Marketing Performance?

b) Does an e-Marketing Capability have a significant effect on Marketing Performance?

\subsection{Research Purpose}

The purpose of this study was to determine the effect of knowledge sharing and e-Marketing performance on marketing performance in incubation business at the University of Pembangunan Nasional "Veteran" East Java.

\section{THEORETICAL FRAMEWORK AND HYPOTHESES DEVELOPMENT}

\subsection{The Relationship Between Knowledge Sharing and e-Marketing Capability}

Knowledge sharing has received much attention in the literature as a form of knowledge management because it is directly related to the performance of business organizations (Cunningham, Seaman, \& McGuire, 2016). Knowledge sharing is also an integral component of knowledge management that helps to transform individual knowledge into organizational 
knowledge and improves organizational performance (Wang, Sharma, \& Cao, 2016). In the model of knowledge sharing, (Takeuchi, 2006) proposes the knowledge sharing model as socialization, externalization, combination, and internalization that are determined to perform functions and processes to create explicit knowledge sharing. On the one hand, knowledge sharing as organizational knowledge becomes an individual or organizational knowledge with the process of internalization and socialization. Furthermore, knowledge sharing can be given to individuals and organizations based on externalization and combination processes. The practice of knowledge sharing throughout business organizations is very important to do and become valuable as an organizational heritage, to learn new things, to help solve problems, to create good competencies and to create new situations for business organizations. One of the advantages of knowledge sharing is to form a marketing capability using information technology (e-Marketing capability) for business organizations. E-Marketing capability is the integration process of a business organization in collecting and using the knowledge and skills to manage internal resources and directly adapt to the external environment through information technology, including internet (Tang, $\mathrm{Fu}, \& \mathrm{Xie}$, 2015).

e-Marketing capability is the ability to use inputs and resources, such as financial and customer loyalty resources, to efficiently produce the desired sales. e-Marketing capability aims to produce a positive influence on the economic value that business organizations make through increasing market demand (Ahmed, Kristal, \& Pagell, 2014). Furthermore, e-Marketing capability is an integrative process, where a business organization uses tangible or intangible resources to understand complexly about consumer needs, create products that are different from competitors and achieve superior brand equity in using available information technology (Yeşil, Koska, \& Büyükbeşe, 2013). Some research results have found that knowledge sharing can have an influence on business organizations in their ability to innovate. In the study (Hu, Horng, \& Sun, 2009) states that the existence of knowledge sharing activities provided by small and medium entrepreneurs can increase the ability in implementing e-Marketing for every business organization facing business competition. Research (Hu, Horng, \& Sun, 2009), states that business organizations need knowledge sharing to manage organizations to respond quickly to the current market situation. Therefore, based on the existing literature and theory, the hypothesis that can be taken is:

\section{$\mathrm{H}_{1}$ : Knowledge sharing has a positive effect on the e-marketing capability}

\subsection{The Relationship Between Knowledge Sharing and Marketing Performance}

Knowledge sharing has received much attention in the literature as a form of knowledge management because it is directly related to the performance of business organizations (Cunningham, Seaman, \& McGuire, 2016). Knowledge sharing serves as a means for an organization to gain knowledge and lead to changes in organizational behavior and performance. Through effective knowledge sharing and learning, business organizations can improve their behavior, improve the ability to innovate, and can perform organizational efficiency to achieve marketing performance (Tang, Fu, \& Xie, 2015). Business organizations carry out a superior strategy to increase profits and create good value. To see whether a business organization can conduct effective and efficient marketing directly to customers is through marketing performance. Marketing performance is a measurement that evaluates the activities carried out by business organizations through the overall marketing process of a business organization (Wang \& Kim, 2017). Marketing performance is a concept used to measure and assess the extent of market performance that has been achieved by a product in a business organization through marketing activities $(\mathrm{Wu}, 2015)$. Some studies state that knowledge sharing affects marketing performance 
due to providing knowledge to business organizations in marketing development to produce significant marketing performance (Tang, Fu, \& Xie, 2015). Therefore, based on the existing literature and theory, the hypothesis that can be taken is:

$\mathrm{H}_{2}$ : Knowledge sharing has a positive effect on marketing performance

\subsection{The Relationship Between e-Marketing Capability and Marketing Performance}

The ability of a business organization in using e-Marketing can provide good image and maintain consumer loyalty as a collective assessment that becomes an evaluation of companies to become innovative companies (Foroudi, Jin, Gupta, Melewar, \& Foroudi, 2016). Business organizations that have e-Marketing capabilities, in general, are defined as an organizational strategy that is open to new ideas and new ways to meet customer needs (Efrat, Gilboa, \& Yonatany, 2017). Innovative ways will have a positive impact on business organizations to improve marketing performance. e-Marketing capability provides a solution for business organizations to add value to the company and help marketing to increase profits in using information technology. Marketing performance is a factor that is used to measure the impact of marketing activities directed to produce marketing performance such as sales volume and sales growth rate as an indicator of the success of the ability to carry out marketing strategies (Najafi-Tavani, Sharifi, \& Najafi-Tavani, 2016). Some studies state that e-Marketing capability can influence marketing performance with new things that attract consumers (Efrat, Gilboa, \& Yonatany, 2017). Therefore, based on the existing literature and theory, the hypothesis that can be taken is:

$\mathrm{H}_{3}$ : e-Marketing capability has a positive effect on marketing performance

\section{RESEARCH METHOD}

\subsection{Research Design}

This research is explanatory research which aims to determine the relationship between research variables which consist of knowledge sharing, e-marketing capability, and marketing performance. The study was conducted at the Business Incubator, Business Administration, Faculty of Social and Political Sciences, UPN "Veteran" East Java, with research subjects being business people registered in Business Incubators, Business Administration, Faculty of Social and Political Sciences, UPN "Veteran" East Java. The reason for choosing the object of research at the Business Incubators, Business Administration, Faculty of Social and Political Sciences, UPN "Veteran" East Java was because the incubator was a platform for students who would start and run a business on campus. This research was conducted in June 2018-July 2018 with the consideration that students were attending training in business incubators. Meanwhile, the research analysis tool used was PLS SEM (Partial Least Squared Structural Equation Model) with a seven levels Likert scale, the seven levels of preference ranges from strongly disagree (1) to strongly agree (7). The selection of SEM as an analytical tool is because this study analyzes the relationship and influence of each variable. 
Table 1 Research Variable and Indicator

\begin{tabular}{|c|c|c|c|}
\hline Variable & Definition & Indicator & Source \\
\hline $\begin{array}{c}\text { Knowledge } \\
\text { Sharing }\end{array}$ & $\begin{array}{l}\text { Knowledge sharing is also } \\
\text { an integral component of } \\
\text { knowledge management } \\
\text { that helps transform } \\
\text { individual knowledge into } \\
\text { organizational knowledge } \\
\text { and improves } \\
\text { organizational } \\
\text { performance }\end{array}$ & $\begin{array}{l}\text { Explore ideas based on } \\
\text { consumer suggestions, } \\
\text { Discuss with consumers in } \\
\text { creating new product and } \\
\text { Receive criticism and } \\
\text { suggestions from } \\
\text { consumers. }\end{array}$ & $\begin{array}{c}\text { ( Wang, Sharma, \& } \\
\text { Cao, 2016) }\end{array}$ \\
\hline $\begin{array}{c}\text { e-Marketing } \\
\text { Capability }\end{array}$ & $\begin{array}{l}\text { E-Marketing capability is } \\
\text { the integration process of } \\
\text { a business organization in } \\
\text { collecting and using the } \\
\text { knowledge and skills to } \\
\text { manage internal resources } \\
\text { and directly adapt to the } \\
\text { external environment } \\
\text { through information } \\
\text { technology, including } \\
\text { internet }\end{array}$ & $\begin{array}{l}\text { Always develop new } \\
\text { products with innovation, } \\
\text { always perfect existing } \\
\text { products with innovations, } \\
\text { always able to respond } \\
\text { well to market changes and } \\
\text { be able to maintain } \\
\text { profitability during market } \\
\text { changes that occur. }\end{array}$ & (Tang, Fu, \& Xie, 2015) \\
\hline $\begin{array}{l}\text { Marketing } \\
\text { Performance }\end{array}$ & $\begin{array}{l}\text { Marketing performance is } \\
\text { a measurement that } \\
\text { evaluates the activities } \\
\text { carried out by business } \\
\text { organizations through the } \\
\text { overall marketing process } \\
\text { of a business organization }\end{array}$ & $\begin{array}{l}\text { The value of our product } \\
\text { sales have increased in the } \\
\text { past one year, the number } \\
\text { of sales of our products has } \\
\text { increased in the past one } \\
\text { year, profitability has } \\
\text { increased in the past one } \\
\text { year, and the volume of } \\
\text { sales in the unit has } \\
\text { increased in the past one } \\
\text { year. }\end{array}$ & ( Wang \& Kim, 2017) \\
\hline
\end{tabular}

\subsection{Population and Sample}

The population in this study are all students who have their own business. As the sampling technique used in the study was to use purposive sampling with the criteria of respondents determined are students who have businesses and also have become suppliers in business incubators, Faculty of Social and Political Sciences, UPN "Veteran" East Java. The total number of respondents who are willing to be observed is 100; this number is considered to be sufficient because it has represented a population of 400 people. 


\subsection{Research Framework}

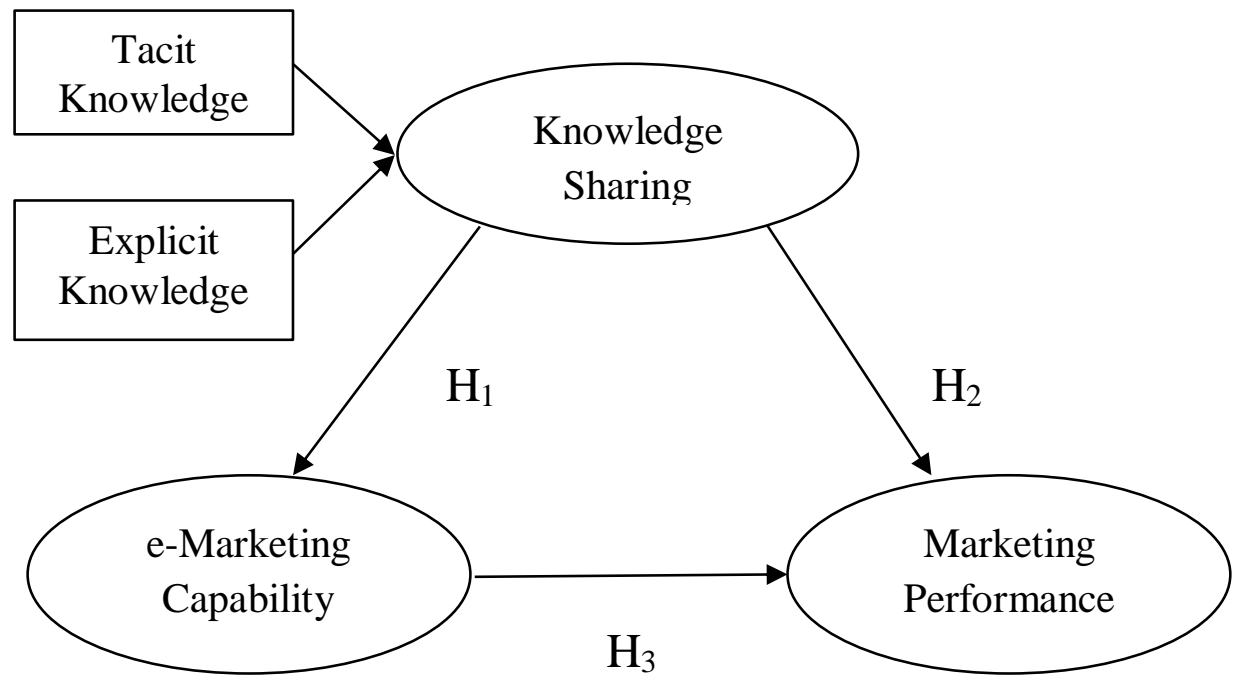

Picture 1 Research Framework

This study employs three main variables; Knowledge sharing, e-Marketing Capability, and Marketing Performance as seen in the table below.

\section{RESEARCH RESULT AND ANALYSIS}

\subsection{Descriptive Analysis}

Characteristics of respondents in the study are presented in the following table.

Table 2 Characteristics of Respondents

\begin{tabular}{|l|c|c|}
\hline \multicolumn{1}{|c|}{ Category } & Frequency & Percentage \\
\hline Sex & 69 & $69 \%$ \\
\hline Male & 31 & $31 \%$ \\
\hline Female & 43 & $43 \%$ \\
\hline Age & 57 & $57 \%$ \\
\hline $15-20$ years old & $55 \%$ \\
\hline $20-25$ years old & 55 & $45 \%$ \\
\hline Duration of business
\end{tabular}

Source: Primary Data Processed, 2018

The results of this study indicate that respondents with male sex were $69 \%$ and female sex were $31 \%$. The categories of respondents aged 15 years old - 20 years old were $43 \%$ and categories of age 20 years - 25 years were $57 \%$. Duration of business owned by students in one year is 55 or $55 \%$, and 45 people or $45 \%$ of respondents have opened their business for longer than a year. Statement/item testing is adapted from the instrument used in the study. Knowledge Sharing variables are adapted from research (Wang \& Wang, 2012) about the knowledge sharing the dimension of tacit knowledge and explicit knowledge. The variable e-Marketing capability testing is by the dimensions of innovation capability and responsive capability (Lai \& Lin, 2012). 
Furthermore, to test the variable marketing performance, it is adapted from the study ( NajafiTavani, Sharifi, \& Najafi-Tavani, 2016) that states the dimensions are divided into sales volume and sales growth rate.

\subsection{Validity and Reliability}

Tables 3, 4, and 5 show that the overall loading factor value on each indicator item has met the criteria of above 0.50 . Variance extracted shows the number of variances of the indicators extracted by the formed variables developed. A high variance extracted value indicates that the indicators have represented well the formalized variables developed. Table 3 shows that the variance extracted have a good AVE value in all constructs, because it meets the cut-off value requirements of equal to or above 0.50 . Reliability is one indicator of convergent validity. Based on table 3,4, and 5, it can be seen that the composite reliability value for each variable is $>0.7$, and the value of Cronbach alpha in each variable is $>0.5$. So it can be concluded that the data used in this study is reliable.

Table 3 Descriptive Statistics, Indicator Loadings, Critical Ratios, Cronbach's Alpha, and AVE of Knowledge Sharing

\begin{tabular}{|c|c|c|c|c|c|}
\hline Questionnaire item & Code & $\begin{array}{c}\text { Factor } \\
\text { Loading }\end{array}$ & $\begin{array}{l}\text { Construct } \\
\text { Reliability }\end{array}$ & $\begin{array}{c}\text { Cronbach } \\
\text { Alpha }\end{array}$ & AVE \\
\hline Explore ideas based on consumer advice & KS2 & 0.852 & \multirow{3}{*}{0.729} & \multirow{3}{*}{0.623} & \multirow{3}{*}{0.610} \\
\hline $\begin{array}{l}\begin{array}{l}\text { Discuss with consumers in creating new } \\
\text { product }\end{array} \\
\end{array}$ & KS6 & 0.582 & & & \\
\hline $\begin{array}{l}\text { Receive criticism and suggestions from } \\
\text { consumers. }\end{array}$ & KS7 & 0.614 & & & \\
\hline
\end{tabular}

Source: Primary Data Processed, 2018

Table 4 Descriptive Statistics, Indicator Loadings, Critical Ratios, Cronbach's Alpha, and AVE of e-Marketing Capability

\begin{tabular}{|c|c|c|c|c|c|}
\hline Questionnaire item & Code & $\begin{array}{c}\text { Factor } \\
\text { Loading }\end{array}$ & $\begin{array}{l}\text { Construct } \\
\text { Reliability }\end{array}$ & $\begin{array}{l}\text { Cronbach } \\
\text { Alpha }\end{array}$ & AVE \\
\hline $\begin{array}{l}\text { We always develop new products with } \\
\text { innovation }\end{array}$ & $\mathrm{MC} 1$ & 0.918 & \multirow{4}{*}{0.893} & \multirow{4}{*}{0.650} & \multirow{4}{*}{0.792} \\
\hline $\begin{array}{l}\text { We always perfect existing products with } \\
\text { innovations }\end{array}$ & $\mathrm{MC} 2$ & 0.925 & & & \\
\hline $\begin{array}{l}\text { We always able to respond well to market } \\
\text { changes }\end{array}$ & MC3 & 0.841 & & & \\
\hline $\begin{array}{l}\text { We can maintain profitability during market } \\
\text { changes that occur. }\end{array}$ & MC4 & 0.572 & & & \\
\hline
\end{tabular}

Source: Primary Data Processed, 2018 
JEMA: Jurnal Ilmiah Bidang Akuntansi dan Manajemen, Vol. 16 No. 1 (2019)

http://riset.unisma.ac.id/index.php/jema (e-ISSN : 2597-4071)

Table 5 Descriptive Statistics, Indicator Loadings, Critical Ratios, Cronbach's Alpha, and AVE of Marketing Performance

\begin{tabular}{|c|c|c|c|c|c|}
\hline Questionnaire item & Code & $\begin{array}{c}\text { Factor } \\
\text { Loading }\end{array}$ & $\begin{array}{l}\text { Construct } \\
\text { Reliability }\end{array}$ & $\begin{array}{c}\text { Cronbach } \\
\text { Alpha }\end{array}$ & AVE \\
\hline $\begin{array}{l}\text { The value of our product sales have increased in } \\
\text { the past year }\end{array}$ & MP1 & 0.675 & \multirow{4}{*}{0.802} & \multirow{4}{*}{0.755} & \multirow{4}{*}{0.802} \\
\hline $\begin{array}{l}\text { The number of sales of our products has } \\
\text { increased in the past year }\end{array}$ & MP2 & 0.836 & & & \\
\hline Profitability has increased in the past year & MP3 & 0.711 & & & \\
\hline $\begin{array}{l}\text { The volume of sales in the unit has increased in } \\
\text { the past year. }\end{array}$ & MP4 & 0.644 & & & \\
\hline
\end{tabular}

Source: Primary Data Processed, 2018

Discriminant validity is a test to see the variable construct is valid or not. Table 6 shows that the value of discriminant validity $>0.6$ so that the overall construct is valid.

Tabel 6 Discriminant Validity

\begin{tabular}{|c|c|c|c|}
\hline Variable & $\begin{array}{c}\text { Knowledge } \\
\text { Sharing }\end{array}$ & $\begin{array}{c}\text { e-Marketing } \\
\text { Capability }\end{array}$ & $\begin{array}{c}\text { Marketing } \\
\text { Performance }\end{array}$ \\
\hline Knowledge Sharing & 0.687 & & \\
\hline e-Marketing Capability & & 0,780 & \\
\hline Marketing Performance & & & 0.912 \\
\hline
\end{tabular}

Source: Primary Data Processed, 2018

\subsection{Research Analysis}

Hypothesis testing is done by using data processing software, SmartPLS, which can be seen in Picture 2 below.



Picture 2 PLS-SEM Result 
Based on Picture 2, it is known that the highest coefficient value for the knowledge sharing variable is $\mathrm{KS} 2$, it is equal to 0.852 which indicates that $\mathrm{KS} 2$ has the strongest correlation among the other indicators, the lowest value is KS6 with 0.582 . The variable e-Marketing capability is MC1 with 0.925 which shows the strongest correlation among other indicators; the lowest value is MC4 with 0.572. The highest value marketing performance variable is MP2 with 0.836 which shows that for KP4, it has the strongest correlation among the other indicators, the lowest value is in MP4 with 0.644.

\subsection{Research Discussion}

Table 7 Path Coefficients (Mean, STDEV, T-Values)

\begin{tabular}{|l|c|c|c|c|c|c|}
\hline & $\begin{array}{c}\text { Original } \\
\text { Sample (O) }\end{array}$ & $\begin{array}{c}\text { Sample } \\
\text { Mean (M) }\end{array}$ & $\begin{array}{c}\text { Std Deviation } \\
(\text { STDEV) }\end{array}$ & $\begin{array}{c}\text { T Statistics } \\
(\mid \mathrm{O} / \text { STDEV })\end{array}$ & P Values & Decision \\
\hline $\begin{array}{l}\text { Knowledge } \\
\text { Sharing } \rightarrow \\
\text { e-Marketing } \\
\text { Capability }\end{array}$ & -0.213 & -0.233 & 0.126 & 1.697 & 0.090 & $\mathrm{H}_{1}$ Rejected \\
\hline $\begin{array}{l}\text { Knowledge } \\
\text { Sharing } \rightarrow \\
\begin{array}{l}\text { Marketing } \\
\text { Performance }\end{array}\end{array}$ & 0.770 & 0.774 & 0.048 & 15.90 & 0.000 & $\begin{array}{c}\mathrm{H}_{2} \\
\text { Accepted }\end{array}$ \\
\hline $\begin{array}{l}\text { e-Marketing } \\
\text { Capability } \\
\text { Marketing } \\
\text { Performance }\end{array}$ & -0.136 & -0.137 & 0.069 & 1.960 & 0,048 & $\mathrm{H}_{3}$ Rejected \\
\hline
\end{tabular}

Source: Primary Data Processed, 2018

Based on the results the first hypothesis test it is known that the significance value of $t$ is obtained at $0,000<0,090$, meaning that the first hypothesis is rejected with a statistical $t$ value of $1,697<\mathrm{t}$ table (1973). So, there is no positive and significant influence between Knowledge Sharing on e-Marketing Capability, the higher the KS it is not necessary to have a positive impact on e-Marketing Capability. Knowledge Sharing is an activity that leads to changes and developments in science including the development of innovative products that can provide satisfaction to consumers. The more frequent knowledge is sharing by business organizations including business incubators, it will have a positive impact on the ability of students to create innovative products. However, the results of this study show that the knowledge shared through a training process does not have a good impact on online marketing skills; intense training is needed so that it has a positive influence. The results of this study are not in line with previous research conducted by ( Hu, Horng, \& Sun, 2009).

The results of the second hypothesis test show that the significance value of $t$ is obtained at $0,000<0,000$, meaning that the second hypothesis is accepted with at value of statistics of $15.90>\mathrm{t}$ table (1973). So, there is a positive and significant influence of Knowledge Sharing on marketing performance; a higher Knowledge Sharing will increase marketing performance. If a business organization including a business unit owned by students gets a discussion forum in the concept of knowledge sharing it will help students to market their product in various marketing concepts and marketing strategies today to improve marketing performance that directs the profitability of the organization. The results of this study support or are consistent with the previous study conducted 
by (Tang, Fu, \& Xie, 2015) which states that knowledge sharing affects marketing performance due to providing knowledge to business units in marketing development to produce significant marketing performance (Tang, Fu, \& Xie, 2015).

The results of the third hypothesis test show that the significance value of $t$ obtained is 0,000 $<0,048$, meaning that the third hypothesis is rejected with a statistical $t$ value of $1,970<\mathrm{t}$ table (1973). So, there is no positive effect between e-Marketing Capability on marketing performance. The more innovative and responsive products are by market demand, it will have an impact on demand so that purchases occur and it can be said that marketing performance is running well, but the results show that it does not influence marketing performance. The results of this study prove empirically that there is no e-Marketing Capability influence in marketing performance (MP). The results of this study are not in line with the results of previous studies conducted by ( Najafi-Tavani, Sharifi, \& Najafi-Tavani, 2016).

\section{RESEARCH CONCLUSION AND LIMITATION}

\subsection{Conclusion}

This research was conducted to determine the relationship between knowledge sharing and emarketing capability to marketing performance. First, the results of the study show that knowledge sharing does not have a positive and significant effect on e-Marketing capability. Knowledge sharing as a process to provide information through a business seminar forum and business training to plant ideas to students so as to produce innovative products and quickly respond to market changes and market demand, but the results of the study show that e-Marketing capability as a variety of marketing capabilities information technology cannot be influenced by knowledge sharing because the knowledge provided is not on target so that it impedes online marketing. Second, knowledge sharing has a positive and significant effect on marketing performance. Knowledge sharing provides information on how to produce products by market developments and market demand so that sales increase, the increasing sales proves that marketing performance is successful when knowledge sharing plays a role. Third, e-Marketing capability as the ability of business units to introduce products to create good value has an impact on marketing performance. If e-Marketing capability in a business unit is good, then marketing performance is also good. However, the e-Marketing capability in this research cannot affect marketing performance. This is because the business units in the Business Incubator cannot meet market demand and keep up with market developments so that marketing performance is less effective in product development.

\subsection{Limitation}

This study has its limitations; it only focused on Knowledge sharing, e-marketing capability, marketing performance. The further researcher is expected to conduct research that studies the characteristics consumer to provide better generalization.

\section{REFERENCES}

Ahmed, M. U., Kristal, M. M., \& Pagell, M. (2014). Impact of operational and marketing capabilities on firm performance: Evidence from economic growth and downturns. International Journal of Production Economics, 154, 59-71. https://doi.org/10.1016/j.ijpe.2014.03.025.

Cacciolatti, L., \& Lee, S. H. (2016). Revisiting the relationship between marketing capabilities and firm performance: The moderating role of market orientation, marketing strategy and 
organisational power. Journal of Business Research, 69(12), 5597-5610. https://doi.org/10.1016/j.jbusres.2016.03.067.

Chari, S., Balabanis, G., Robson, M. J., \& Slater, S. (2017). Alignments and misalignments of realized marketing strategies with administrative systems: Performance implications. Industrial Marketing Management, 63, 129-144. https://doi.org/10.1016/j.indmarman.2016.11.002.

Chuang, S. (2016). Facilitating the chain of market orientation to value co-creation: The mediating role of e-marketing adoption. Journal of Destination Marketing \& Management. https://doi.org/10.1016/j.jdmm.2016.08.007.

Cunningham, J., Seaman, C., \& McGuire, D. (2016). Knowledge sharing in small family firms: A leadership perspective. Journal of Family Business Strategy, 7(1), 34-46. https://doi.org/10.1016/j.jfbs.2015.10.002.

Efrat, K., Gilboa, S., \& Yonatany, M. (2017). When marketing and innovation interact: The case of born-global firms. International Business Review, 26(2), 380-390. https://doi.org/10.1016/j.ibusrev.2016.09.006.

Foroudi, P., Jin, Z., Gupta, S., Melewar, T. C., \& Foroudi, M. M. (2016). Influence of innovation capability and customer experience on reputation and loyalty. Journal of Business Research, 69(11), 4882-4889. https://doi.org/10.1016/j.jbusres.2016.04.047.

Hu, M. M., Horng, J., \& Sun, Y. C. (2009). Hospitality teams : Knowledge sharing and service innovation performance. Tourism Management, 30(1), 41-50. https://doi.org/10.1016/j.tourman.2008.04.009.

Lai, Y.-L., \& Lin, F.-J. (2012). The Effects of Knowledge Management and Technology Innovation on New Product Development Performance An Empirical Study of Taiwanese Machine Tools Industry. Procedia - Social and Behavioral Sciences, 40, 157-164. https://doi.org/10.1016/j.sbspro.2012.03.176.

Monim, A., \& West, D. C. (2010). Industrial Marketing Management The measurement of emarketing orientation ( EMO ) in business-to-business markets. Industrial Marketing Management, 39(7), 1097-1102. https://doi.org/10.1016/j.indmarman.2009.06.011.

Najafi-Tavani, S., Sharifi, H., \& Najafi-Tavani, Z. (2016). Market orientation, marketing capability, and new product performance: The moderating role of absorptive capacity. Journal of Business Research, 69(11), 5059-5064. https://doi.org/10.1016/j.jbusres.2016.04.080.

Prayogo, R. R., \& Kusumawardhani, A. (2016). Examining Relationships of Destination Image, Service Quality, e-WOM, and Revisit Intention to Sabang Island, Indonesia. Asia-Pacific Management and Business Application, 5(2), 85-96. Retrieved from http://apmba.ub.ac.id.

Ritala, P., Olander, H., Michailova, S., \& Husted, K. (2015). Knowledge sharing, knowledge leaking and relative innovation performance: An empirical study. Technovation, 35, 22-31. https://doi.org/10.1016/j.technovation.2014.07.011.

Salo, J. (2017). Social media research in the industrial marketing field: Review of literature and 
future research directions. Industrial Marketing Management, 66(April), 115-129. https://doi.org/10.1016/j.indmarman.2017.07.013.

Takeuchi, H. (2006). The New Dynamism of the Knowledge-Creating Company. Japan, Moving toward a More Advanced Knowledge Economy: Advanced Knowledge-Creating Companies, 1-10. Retrieved from http://books.google.com/books?hl=en\&lr=\&id=DJvWa40EqN0C\&oi=fnd\&pg=PA1\&dq=The + New+Dynamism+of+the+Knowledge-

Creating+Company\&ots=e1aB1tZvCK\&sig=bzmINUML-xUKnhMEaUSMTKxuiTM

Tang, T. P., Fu, X., \& Xie, Q. (2015). Influence of functional conflicts on marketing capability in channel relationships. Journal of Business Research, 78, 252-260. https://doi.org/10.1016/j.jbusres.2016.12.020.

Trainor, K. J., Rapp, A., Beitelspacher, L. S., \& Schillewaert, N. (2011). Integrating information technology and marketing: An examination of the drivers and outcomes of e-Marketing capability. Industrial Marketing Management, 40(1), 162-174. https://doi.org/10.1016/j.indmarman.2010.05.001.

Wang, Z., \& Kim, H. G. (2017). Can Social Media Marketing Improve Customer Relationship Capabilities and Firm Performance? Dynamic Capability Perspective. Journal of Interactive Marketing, 39, 15-26. https://doi.org/10.1016/j.intmar.2017.02.004.

Wang, Z., Sharma, P. N., \& Cao, J. (2016). From knowledge sharing to firm performance: A predictive model comparison. Journal of Business Research, 69(10), 4650-4658. https://doi.org/10.1016/j.jbusres.2016.03.055.

Wang, Z., \& Wang, N. (2012). Knowledge sharing, innovation and firm performance. Expert Systems with Applications, 39(10), 8899-8908. https://doi.org/10.1016/j.eswa.2012.02.017.

$\mathrm{Wu}, \mathrm{C} . \mathrm{W}$. (2015). The international marketing strategy modeling of leisure farm. Journal of Business Research, 69(4), 1345-1350. https://doi.org/10.1016/j.jbusres.2015.10.105.

Yeşil, S., Koska, A., \& Büyükbeşe, T. (2013). Knowledge Sharing Process, Innovation Capability and Innovation Performance: An Empirical Study. Procedia - Social and Behavioral Sciences, 75, 217-225. https://doi.org/10.1016/j.sbspro.2013.04.025.

Yu, W., Ramanathan, R., \& Nath, P. (2017). Environmental pressures and performance: An analysis of the roles of environmental innovation strategy and marketing capability. Technological Forecasting and Social Change, 117, 160-169, https://doi.org/10.1016/j.techfore.2016.12.005.

*) Lia Nirawati, Department of Business Administration, University of Pembangunan Nasional Veteran, Surabaya, Indonesia (Email: lianirawati@gmail.com)

**) Rangga Restu Prayogo, Department of Business Administration, University of Pembangunan Nasional Veteran, Surabaya, Indonesia (Email: ranggarestuprayogo@gmail.com) 